was got out, and numerous examples of the leaf-impressions were secured.

This section has been referred to by J. Starkie Gardner, * who notes the occurrence of Taxodium Europaum, Platanus, Onoclea, Pteris, Osmunda, etc., here and at other places, the whole having a remarkably temperate aspect. These forms were afterwards driven northwards by warmer conditions in the time of the London Clay. Mr. Whitaker also remarked generally on the section. Some fossils were afterwards obtained from an adjacent pit now worked out.

After tea at the Abbey Café, the Abbey ruins and the museum were visited, and the party returned to London.

The heights of the sections of gravel visited are as follows :-

\begin{tabular}{|c|c|c|c|c|c|c|}
\hline \multirow[b]{2}{*}{ Kensington Road } & & \multicolumn{3}{|c|}{ Above river. } & \multicolumn{2}{|c|}{ Above sea-level. } \\
\hline & & $\ldots$ & $22 \mathrm{ft}$. & $\cdots$ & ... & I $44 \mathrm{ft}$. \\
\hline Tilehurst Road ... & $\ldots$ & $\ldots$ & $75 \mathrm{ft}$. & ... & $\ldots$ & I $97 \mathrm{ft}$. \\
\hline Norcot & $\ldots$ & $\ldots$ & I $72 \mathrm{ft}$. & $\ldots$ & $\ldots$ & $294 \mathrm{ft}$. \\
\hline
\end{tabular}

\title{
REFERENCES.
}

Geol. Survey Map, Sheet 268, New Series.

O. A. Shrubsole.-- On the Valley-Gravels about Reading, with especial reference to the Palæolithic Implements found in them." Quart. Fourn. Geol. Soc., xlvi., p. 582.

H. W. Monckton.- "On the Occurrence of Boulders and Pebbles from the Glacial Drift in Gravels South of the Thames." Quart. Fourn. Geol. Soc., xlix., p. 308.

W. Whitaker.- "Geology of the London Basin." Mem. Geol. Survey, vol. iv.

\section{EXCURSION TO HEADINGLEY, SHOTOVER, AND WHEATLEY.}

JUNE 7 TH, I902.

Director: Rev. J. F. Blake, M.A, F.G.S.

Excursion Secretary: A. C. Young, F.C.S.

(Report by THE DIRECTOR).

ThE excursion commenced at the tram terminus, on the Cowley Road from Oxford. This lies on a nearly level surface of Oxford clay. Taking the footpath that leads thence towards Headingley, a low feature over which the path rises marks the commencement of the Lower Calcareous Grit, and the soil thereafter becomes sandy. After reaching the high road, a recently made excavation was found on the left hand side, which showed some to ft. or so of the grit, and it was found to contain here some inpersistent bands of calcareous stone of a rough character, without observable fossils, and these it was stated are found for 
some distance down. As such bands are seldom seen in natural exposures of the sand, it is to be supposed that in such situations they have been dissolved out (see Phillips' Geology of Oxford, p. 299). The gradual rise to the base of the Coral Rag does not indicate any great thickness here, probably not more than $60 \mathrm{ft}$. The first quarry of limestone visited was the well-known Windmill quarry, showing the Calcareous Grit with doggers at the base and the variable Coral Rag, with very little solid material between it and the Grit. Its dip towards the hill was noticed, and its Thecosmilian character, but the approach of a thunderstorm drove the members to seek shelter.

The next quarry visited was a deep one, nearly opposite the vicarage. The lower part is composed of rough Coral Rag, as in the last quarry, with fragments of the outer whorl of Am. varicostatus, but the upper half consists of massive shell débris, obviously the washings of material like the lower half.

At the corner of the road to Shotover, the next succeeding stage was seen, where this same massive rock was being quarried in an 8 or $\mathbf{1} \circ \mathrm{ft}$. face, and overlaid by a few feet of dark blue Kimeridge Clay. The junction of this with the light grey stone makes an admirable contrast, and is seen to be highly irregular as though by weathering. So sharp is the junction that it suggests at first sight that the clay has slipped forward; but this possibility is negatived by the occurrence of undisturbed hard bands in the clay. Nests of Bel. explanatus were here observed in the Kimeridgian.

From this quarry the ascent becomes rapid, and the next opening, or brickyard, shows Kimeridge Clay at the base, apparently on a higher horizon than that previously seen, the nodules containing a Perisphinctes allied to $P$. thurmanni. Just above the level of these the sandy matrix of the Lower Portlandian commences, and gradually becomes a more massive stone, in which $P$. pectinatus was found by Phillips and by later collectors. It is not easy to distinguish on this hill any line of junction between the Portlandian sand and the overlying Shotover freshwater sands, but the former are more argillaceous, and the latter more ferruginous. It is, however, known that the upper deposit must be unconformable, because the true Portland Limestone, with Trigonia gibbosa, occurs about two miles away at Garsington and Cuddesdon. There was no time, however, to visit these localities.

The Shotover Sands form a kind of plateau from which a fine view is obtained, but which affords no exposures. The next pit visited was therefore the brickyard near Wheatley, south of the railway, where was seen the same Kimeridge Clay with Ammonites as before, but nothing higher. At the same level on the north side of the railway occurs the Corallian Limestone, so that the fault on the Survey map must indicate a throw of about roo ft.

After tea at Wheatley, three quarries of the Corallian Limestone 
were examined-one at the west end of the village, one just behind it at the junction of two roads*, and a third at some distance away at the turning to Stanton St. John. All the deposits in these quarries are of like character, consisting of a series of bands of fine shell brash, scarcely to be called an oolite, alternating with thicker beds of the same material compacted into building stone of uniform character. This is no more than a greater expansion-. some $3 \circ \mathrm{ft}$. probably $-\mathrm{cf}$ the material seen overlying the Rag at the Headington quarries. No corals are seen here, but the ordinary molluscan fauna of Corallian species is not uncommon. The idea presented is that Headington was the centre of the coral growth, and from thence the débris of it has been spread out on all sides.

The loss of time at Headington, owing to the storm, necessitated, for the carrying out of the programme, a sharp walk back to Oxford.

\section{REFERENCES.}

Geological Survey Maps, Old Series, Sheets I 3 N.E. and 45 S.F.

One inch Ordnance Map, Sheet 237 (New Series).

I87 I. J. PHILI.rPS. - "Geology of Oxford," pl. xvi.

1877. J. F. BLAKE and W. H. HUDLESTON.-"The Corallian Rocks of England," Quart. Fourn. Geol. Soc., vol. xxxiii, pp. 308-3I I.

1880. J. F. Bi.ake.- "The Portland Rocks of England," Quart. Fourn. Geol. Soc., vol. xxxvi, pp. 2I3-2I5.

189I. Record of Excursions. "Excursion to Oxford," pp. $244-249$.

EXCURSION TO THE VALLEY OF THE MOLE, BROCKHAM, REIGA'TE AND REDHILL.

JUNE I4TH, 1902.

Directors: W. P. D. Stebeing, F.G.S., and William Whitaker B.A., F.R.S.

Excursion Secretary: E. W. Skeats, D.Sc., F.G.S.

(Report by W. P. D. STEBbing.)

CONSIDERING the weather at the beginning of the day a fair sized party essayed this walk between two of the valleys that cut the escarpment of the N. Downs.

Starting from Dorking Station (L.B. \& S.C.R.) the party first walked up to Burford Bridge, where, in the grounds of Fredley one of the swallow-holes for which the Mole is famous was inspected by the kind permission of Mrs. Kay and Miss Drummond. This hole, which only works when the river is fairly high, was now

\footnotetext{
*In this quarry is an interesting relic of rougher times in a walled chamber with a pyramidal roof, which was formerly used as a kind of pound to lock tip drunken men in.
} 